
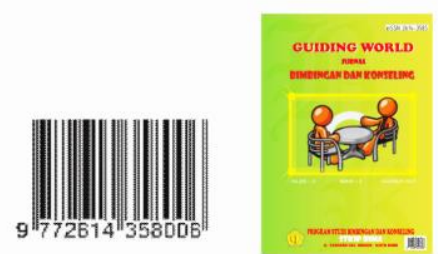

GUIDING WORLD JURNAL BIMBINGAN

DAN KONSELING

Volume 2 Nomor 2

November 2019

E-ISSN : 2614-3585

DOI: 1033627

\title{
Korelasi Antara Konsep Diri dengan Prestasi Belajar Peserta Didik
}

\author{
Faijin, Nurhayati, Muhamadiah \\ Program Studi Bimbingan dan Konseling, STKIP Bima \\ email : wongfaijin@gmail.com \\ sophynurhayati@yahoo.co.id
}

\begin{abstract}
Abstrak
Konsep diri adalah suatu pandangan, persepsi dan perasaan seseorang tentang dirinya baik yang bersifat fisik, psikis, motivasi, kepandaian, kegagalan atau kelemahan dan kelebihannya. Sedangkan prestasi belajar adalah hasil belajar dari suatu aktivitas belajar yang di lakukan berdasarkan pengukuran dan penilaian terhadap hasil kegiatan belajar dalam bidang akademik yang diwujudkan berupa angka-angka dalam raport. Rumusan masalah dalam penelitian ini adalah apakah ada korelasi antara konsep diri dengan prestasi belajar peserta didik kelas XI pada SMA Negeri I Woha Kabupaten Bima. Adapun tujuan dalam penelitian ini adalah untuk mengetahui korelasi antara konsep diri dengan prestasi belajar pesrta didik kelas XI pada SMA Negeri I Woha Kabupaten Bima. Hipotesis alternative $(\mathrm{Ha})$ dalam penelitian ini adalah ada korelasi antara konsep diri dengan prestasi belajar peserta didik kelas XI pada SMA Negeri I Woha. Jenis penelitian ini adalah penelitian kuantitatif korelasional, sebab penelitian ini bertujuan untuk melihat korelasi antara dua variable, metode pengumpulan data yang digunakan adalah angket dan dokumentasi. Data didasarkan pada indikator-indikator konsep diri antara lain keadaan fisik, psikis, motivasi, kepadaian, kegagalan atau kelemahan dengan jumlah pertanyaan sebanyak 60 item dengan skor 4 (selalu),3 (sering), 2 (kadangkadang) dan 1 (tidak pernah). Data yang dianalisis dalam penelitian ini berupa data-data numerik atau angka yang diolah dengan metode statistic coovisien corelation product moment. Berdasarkan hasil analisis data penelitian menunjukkan korelasi $\left(r_{x y}\right)$ sebesar 0,772 dengan $r_{\text {tabel }}=0,312$ dengan demikian maka Ha di terima dan Ho di tolak. Hal tersebut menunjukkan bahwa ada korelasi positif yang kuat antara konsep diri dengan prestasi belajar peserta didik kelas XI pada SMA Negeri I Woha Kabupaten Bima.
\end{abstract}

Kata Kunci : Konsep diri, prestasi belajar

\section{PENDAHULUAN}

Pendidikan adalah usaha sadar dan terencana mewujudkan suasana belajar dan proses pembelajaran agar peserta didik secara aktif mengembangkan potensi dirinya untuk memiliki kekuatan spiritual keagamaan, pengendalian diri, kepribadian, kecerdasan, akhlak mulia, serta keterampilan yang diperlukan dirinya, masyarakat, bangsa dan Negara (UU Sisdiknas, No 20 tahun 2003). 

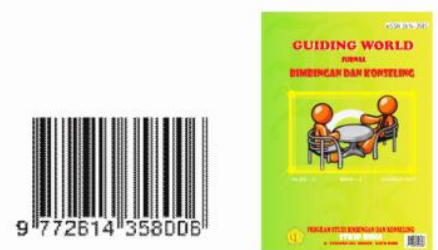

GUIDING WORLD JURNAL BIMBINGAN

DAN KONSELING

Volume 2 Nomor 2

November 2019

E-ISSN : 2614-3585

DOI: 1033627

Untuk mencapai prestasi belajar yang baik tidak jarang peserta didik mendapatkan hambatan-hambatan baik yang bersumber dari dalam diri peserta didik maupun dari luar. Djumhur dan Surya (1981: 32-38) mendefinisikan sedikitnya ada Enam permasalahan pribadi yang dihadapi oleh peserta didik di sekolah yaitu: masalah pengajaran atau belajar, masalah pendidikan, masalah pekerjaan, masalah penggunaan waktu senggang, masalah-masalah sosial dan masalah-masalah pribadi.

Dalam Kamus Besar Bahasa Indonesia, konsep diri berarti rancangan atau pengertian yang diabstrakkan dari peristiwa konkrit dan kata diri berarti orang atau seorang tidak dengan orang lain (Depdikbud, 1990:456). Sedangkan dalam buku lain ditegaskan bahwa konsep diri diartikan sebagai kesadaran individu dari dirinya sendiri (Loekmono, 1992:51). Jadi konsep diri dalam penelitian ini adalah pengertian tentang diri seorang individu yang disebabkan oleh peristiwa konkrit serta menimbulkan tingkah laku yang meliputi bakat, minat, hasil belajar dan citacita. Dalam dunia pendidikan mendapatkan prestasi belajar yang tinggi merupakan sesuatu yang diidamkan oleh semua pihak, tidak hanya peserta didik itu sendiri lebih-lebih bagi orang tua dan keluarga serta orang-orang yang ada disekitar. Untuk mencapai prestasi tersebut tidak hanya dibutuhkan kemampuan pemahaman terhadap apa yang dipelajari tetapi sangat ditentukan oleh cara peserta didik itu sendiri dalam mengolah seluruh aspek dalam dirinya sehingga menimbulkan perilaku belajar yang baik. Jika peserta didik mempunyai konsep diri yang baik maka mereka akan mampu memperoleh prestasi belajar yang lebih baik.

Seperti yang dialami oleh peserta didik di SMA Negeri 1 Woha Kabupaten Bima, prestasi belajar mereka sebenarnya tidak terlalu mengecewakan baik di tingkat kecematan maupun di tingkat kabupaten, namun hal tersebut diatas terjadi karena banyak peserta didik yang mengalami masalah-masalah lain terutama yang menyangkut bakat, minat, hasil belajar dan cita-cita. Dengan demikian tidak berlebihan jika dikatakan bahwa sebagian peserta didik memperoleh prestasi belajar yang kurang memuaskan disebabkan peserta didik tidak mampu memahami kemampuan yang ada dalam diri mereka.

Berdasarkan paparan di atas, peneliti tertarik untuk meneliti lebih lanjut mengenai "Korelasi antara konsep diri dengan prestasi belajar peserta didik". Tujuan dari penelitian ini adalah untuk mengetahui apakah ada hubungan antara konsep diri dengan prestasi belajar peserta didik. Manfaat yang diperoleh yaitu peserta didik dapat memahami dan memiliki pandangan positif tentang dirinya dalam mendukung proses pembelajaran di sekolah sehingga mendapatkan hasil belajar yang lebih baik. Adapun hipotesis dalam penelitian adalah ada korelasi positif antara konsep diri dengan prestasi belajar peserta didik pada SMA Negeri 1 Woha Kabupaten Bima.

\section{PEMBAHASAN}

\section{Konsep Diri}

Konsep diri berasal dari bahasa inggris yaitu self concept merupakan suatu konsep mengenai diri individu itu sendiri yang meliputi bagaimana seseorang 

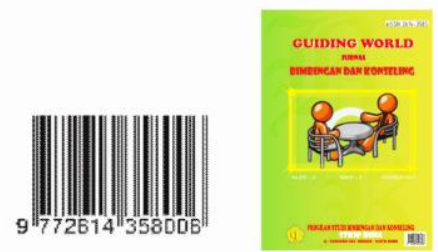

GUIDING WORLD JURNAL BIMBINGAN

DAN KONSELING

Volume 2 Nomor 2

November 2019

E-ISSN : 2614-3585

DOI: 1033627

memandang, memikirkan, dan menilai dirinya sehingga tindakan tindakannya sesuai dengan konsep tentang dirinya tersebut (WWW.Dunia psikologi. Com / konsep diri). Menurut ( Rahman.1991) menyatakan bahwa konsep diri adalah suatu pandangan dan perasaan seseorang tentang dirinya, ini dapat bersikap psikis maupun sosial. Sejalan dengan pendapat tersebut di kemukakan oleh cawangas (Pudjijogyanti, 1988) bahwa konsep diri merupakan seluruh pandangan individu tentang dimensi fisiknya, psikisnya, motivasinya, kepandaian, kegagalan atau kelemahanya. Konsep diri (self concept) juga berarti "pikiran atau persepsi seorang tentang dirinya sendiri, dan merupakan salah satu faktor penting yang mempengaruhi tingkah laku (Soemanto,1983:175). Dalam buku lain ditegaskan bahwa konsep diri diartikan sebagai kesadaran individu dari dirinya sendiri (Loekmono, 1992:51).

Berdasarkan uraian di atas bahwa yang dimaksud dengan konsep diri adalah suatu pandangan, persepsi dan perasaan seseorang tentang dimensi dirinya baik yang bersifat fisik, psikis, motivasi, kepandaian, kegagalan atau kelemahan maupun bersifat kepribadaian.

Sunartana (1976:15) menjelaskan aspek-aspek tentang konsep diri berkembang dari suatu instrument yang dikenal dengan Who am I. Aspek-aspek konsep diri dimaksud meliputi : (1) Sangup membuat rencana, (2) Bermain dan bergaul dengan teman sebaya, (3) Pengertian terhadap sesuatu, (4) Memperoleh teman, (5) Mengemukakan pendapat, (6) Memenuhi harapan orang lain, (7) Membuat gagasan (8) Jumlah teman, (9) Kepemimpinan, (10) Sikap terhadap norma, (11) Bekerja untuk keluarga, (12) Masalah kebahagiaan,

Kepopuleran

Konsep diri merupakan totalitas kepribadian seseorang individu yang tidak bisa dipisahkan dari tiga aspek dalam diri manusia yaitu aspek kognitif, afektif, dan pskomotor. Loekmono (1992), Faktor yang mempengaruhi konsep diri anak (self concept) adalah sebagai berikut:

a. Faktor Lingkungan

Dalam buku yang berjudul "Harga Diri" disebutkan bahwa gambaran atau citra diri adalah kesadaran diri dari mental dan karakteristik fisik seseorang. Proses pembentukan gambaran diri ini diawali dalam keluarga, sebab melalui orang tualah seseorang anak mendapat citra diri yang baik, apakah dia dicintai atau ditolak apakah ia pandai atau bodoh. Melalui komunikasi dengan kata-kata atau bahasa tubuh citra diri dari orang tua ini direkam oleh anak. Proses ini makin menjadi berkurang atau menjadi pasif sebab seseorang anak berkembang termasuk didalamnya adalah inisiatif atau prakarsa anak untuk mandiri dan juga karakteristik pribadinya.

b. Faktor Pendidikan

Lembaga pendidikan serta proses pendidikan yang dilalui oleh seorang anak ternyata dapat berpengaruh terhadap pembentuk konsep diri seseorang. Sekolah tempat melanjutkan perkembangan citra diri seseorang anak, pada awalnya ia belajar yang terpuji dan tercela, apa yang boleh dilakukan dan yang dilarang baik dari guru atau teman sebaya. Sekolah juga tempat melatih mental dan karakteristik phisik.

c. Faktor Pengalaman

Faijin, Nurhayati, Muhamadiah 

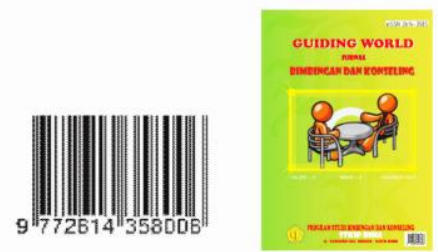

GUIDING WORLD JURNAL BIMBINGAN

DAN KONSELING

Volume 2 Nomor 2

November 2019

E-ISSN : 2614-3585

DOI: 1033627

Pengalaman pribadi seseorang juga dapat berpengaruh terdapat konsep diri anak. Dalam hal ini seorang ahli menyatakan: "Dengan kematangan pengalaman pribadi yang menyeluruh seseorang dapat mengevaluasi lebih realistis seperti seorang pribadi menjadi lebih efisien, matang secara menyeluruh dan tak mudah terpengaruh. Pengalaman individu yang pertama akan diteruskan dan mempengaruhi prilakunya masa sekarang dan masa mendatang.

\section{Prestasi Belajar}

Setiap orang memiliki keinginan untuk lebih baik dalam segala aktivitas baik dalam lingkungan sekolah maupun dalam lingkungan sosial lainya. Walaupun semua orang menginginkanya tetapi tidak semua orang mendapatkan sesuai dengan apa yang diinginkanya tersebut, hal ini dapat dipengaruhi oleh berbagai faktor salah satunya adalah konsep diri.

Prestasi belajar didefinisikan secara berbeda-beda. Hal ini disebabkan karena sudut pandang mereka yang berbeda-beda dalam melihat suatu masalah. Sehubungan dengan hal tersebut, dibawah ini akan dikemukakan batasan pengertian prestasi belajar menurut beberapa ahli.

Prestasi adalah sebagai bukti keberhasilan yang dicapai (Winkel, 1984:162). Ahli lain menyatakan bahwa "Prestasi itu biasa disebut kecakapan nyata, kecakapan actual (actual ablity) yang diperoleh seseorang setelah ia belajar suatu pengetahuan tertentu" (Nurkencana, 1983:2). Jadi prestasi belajar merupakan suatu pengalaman atau kecakapan baru yang diperoleh dari hasil interaksi yang dilakukan.

Prestasi belajar ini pada dasarnya dinyatakan dengan nilai (angka), maka berarti besar kecilnya nilai yang diperoleh menunjukkan besar kecilnya perubahan yang dialami peserta didik. Apabila peserta didik mendapat nilai tinggi berarti prestasi yang didapat dianggap baik. Sebaliknya, apabila peserta didik memperoleh nilai yang kurang berarti prestasi belajar yang dimiliki dianggap kurang atau rendah. Setiap peserta didik memperoleh prestasi belajar yang bebeda-beda sesuai kemampuan masing-masing.

Dari pengertian di atas, dalam lingkup penelitian ini peneliti cenderung pada pendapat yang menyatakan bahwa prestasi belajar itu biasanya disebut kecakapan nyata, kecakapan actual (actual ablity) yang diperoleh seseorang setelah melakukan interaksi dengan lingkungan.

Belajar sebagai proses perubahan atau sebagai bentuk aktifitas individu selalu dipengaruhi oleh bermacam-macam faktor. Dalam buku Psikologi Pendidikan dijelaskan bahwa : Berhasil atau tidaknya belajar itu tergantung kepada bermacam-macam faktor. Adapun faktor itu dapat kita bedakan menjadi dua, yaitu : (a) Faktor yang berasal pada diri individu itu sendiri, yang kita sebut sebagai faktor internal, ( b) faktor yang berasal dari luar individu atau faktor eksternal (Suryabrata, 2002:233). Ahli lain berpendapat untuk mencapai hasil yang sebaik-baiknya, maka haruslah diperhatikan faktor-faktor yang terdapat didalam proses belajar itu sendiri. Dalam belajar akan kita dapati adanya: (1) Faktor anak atau individu yang belajar, (2) Faktor limgkungan anak, (3) Faktor bahan atau materi yang dipelajari (Walgito, 1993:120). 

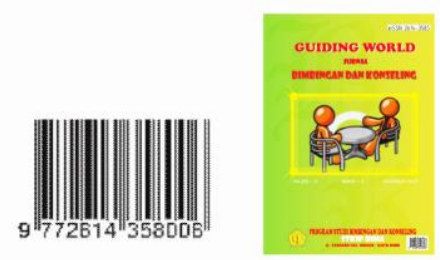

GUIDING WORLD JURNAL BIMBINGAN

DAN KONSELING

Volume 2 Nomor 2

November 2019

E-ISSN : 2614-3585

DOI: 1033627

Faktor-faktor yang mempengaruhi belajar banyak jumlahnya tetapi dapat digolongkan menjadi dua golongan saja, yaitu: Faktor internal dan faktor eksternal. Faktor internal adalah faktor yang ada dalam diri individu yang sedang belajar, sedangkan Faktor eksternal adalah faktor yang ada di luar individu (Slamento, 1988:15).

\section{Faktor Internal}

Faktor internal merupakan factor yang berasal dari dalam diri peserta didik sendiri meliputi dua aspek, yakni: Aspek fisiologi (yang bersifat jasmaniah) dan Aspek psikologi (yang bersifat rohaniah).

2. Faktor Eksternal

Faktor eksternal adalah faktor yang berasal dari luar diri individu/peserta didik yang belajar dan dapat dibedakan atas beberapa jenis. Slamento, (2003:60), menyatakan bahwa: faktor yang berpengaruh terhadap belajar atau yang menentukan berhasil atau tidaknya itu dikelompokkan menjadi 3 (faktor) yang meliputi antara lain: faktor keluarga/keadaan rumah tangga, faktor sekolah, dan faktor masyarakat.

Faktor eksternal diatas diuraikan sebagai berikut: (a) Faktor keluarga yang terdiri dari cara mendidik anak, hubungan orang tua, teladan dari orang tua, (b) Sekolah, yang terdiri dari cara penyajian yang kurang baik, hubungan guru/murid yang kurang baik, hubungan antara anak dengan temannya kurang baik atau kurang menyenangkan, standar pelajaran ada di atas ukuran normal kemampuan anak, alat-alat pelajaran di sekolah kurang lengkap, kurikulum kurang baik, waktu sekolah kurang baik, keadaan gedung sekolah kurang baik, pelaksanaan dispilin yang kurang baik, (c) Masyarakat yang terdiri dari media, teman-teman bergaul dan corak kehidupan tetangga.

\section{METODE PENELITIAN}

\section{Rancangan Penelitian}

Penelitian ini menggunakan penelitian kuantitatif korelasional. Sebab penelitian ini bertujuan untuk mengetahui kekuatan hubungan atau bentuk arah hubungan antara dua variabel. Data yang di analisis dalam penelitian berupa datadata numerical atau angka yang diolah dengan metode statistik, setelah diperoleh hasilnya, kemudian dideskripsifkan dengan menguraikan kesimpulan yang didasari oleh angka yang diolah dengan metode statistik.

\section{Populasi dan Sampel}

Populasi dalam penelitian ini adalah seluruh peserta didik kelas XI pada SMA Negeri 1 Woha yang berjumlah 200 orang. Sampel yang digunakan dalam penelitian ini adalah mengacu pada pendapat Arikunto (2002) jika jumlah populasi besar maka sampel yang dapat diambil antara 10-15\% atau lebih. Tehnik pengambilan sampel yang digunakan ialah dengan tehnik random sampling yaitu pengambilan sampel secara acak dengan cara undian karena setiap populasi yang ada memeiliki kesempatan yang sama untuk dijadikan sampel penelitian. Sehingga sampel dalam penelitian ini berjumlah 40 orang. 


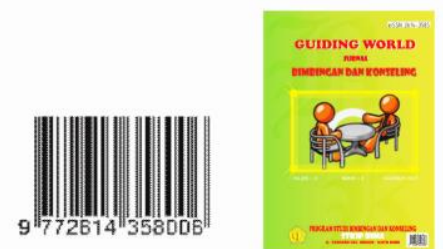

DOI: 1033627
GUIDING WORLD JURNAL BIMBINGAN

DAN KONSELING

Volume 2 Nomor 2

November 2019

E-ISSN : 2614-3585

\section{Instrumen Penelitian}

Adapun beberapa instrument yang dijadikan alat pengumpulan data dalam penelitian ini adalah angket dan catatan dokumentasi. Angket disusun dengan menggunakan skala Likert yang digunakan untuk mengukur konsep diri peserta didik. Alternatif jawaban yang disediakan yaitu." selalu (SL), sering (Sr), kadang-kadang (KK), dan tidak pernah (TP). Pemberian skor untuk tiap item positif adalah sebagai berikut: $\mathrm{SL}=4, \mathrm{Sr}=3, \mathrm{KK}=2$, dan $\mathrm{TP}=1$. Sedangkan item negative adalah $\mathrm{SL}=1, \mathrm{Sr}=2, \mathrm{KK}=3$, dan $\mathrm{TP}=4$.

\section{Tehnik Analisis Data}

Data utama yang diperoleh melalui angket dianalisis dengan menggunakan rumus korelasi product moment. Analisis korelasi produk moment dilakukan untuk mengetahui kekuatan hubungan antara variabel $X$ (Konsep diri) dan variable Y (prestasi belajar) atau digunakan untuk menguji hipotesis yang diajukan. Adapun rumus koefisien korelasi produck moment yang digunakan adalah sebagai berikut :

$$
r_{x y}=\frac{N \sum X Y-\left(\sum X\right)\left(\sum Y\right)}{\sqrt{N\left[\sum X^{2}-\left(\sum X\right)^{2}\right]\left[N \sum Y^{2}-\left(\sum Y\right)^{2}\right]}}
$$

Dimana:

$r=$ Pearson $r$ correlation coefficient

$\mathrm{N}=$ Jumlah sampel

\section{HASIL PENELITIAN}

Berdasarkan analisis data penelitian menunjukkan korelasi $\left(\mathrm{rx}_{\mathrm{y}}\right)$ sebesar 0,772 dengan $\mathrm{r}_{\text {tabel }}=0,312$ maka Ha diterima. Hal tersebut menunjukkan bahwa ada korelasi antara konsep diri dengan prestasi belajar peserta didik kelas XI pada SMAN I WOHA Kabupaten Bima.

Adapun kontribusi kekuatan hubungan konsep diri terhadap prestasi belajar berdasarkan hasil penelitian ini dapat di lihat pada tabel di bawah ini.

Tabel 4.1. Tingkat kekuatan hubungan

\begin{tabular}{|c|c|c|}
\hline No & Nilai (r) & Tingkat hubungan \\
\hline 1 & $0,00-0,199$ & Sangat lemah \\
\hline 2 & $0,20-0,399$ & Lemah \\
\hline 3 & $0,40-0,599$ & Cukup \\
\hline
\end{tabular}

Faijin, Nurhayati, Muhamadiah 
Volume 2 Nomor 2

November 2019

DOI: 1033627

E-ISSN : 2614-3585

\begin{tabular}{|c|c|c|}
\hline 4 & $0,60-0,799$ & Kuat \\
\hline 5 & $0,80-0,100$ & Sangat kuat \\
\hline
\end{tabular}

Sumber : Syofian Siregar (statistic parametric)

Tabel 4.2. Kontribusi konsep diri terhadap prestasi belajar peserta didik kelas XI pada SMA N I WOHA Kabupaten Bima Kategori tinggi

\begin{tabular}{|c|l|c|c|c|}
\hline No & Responden & X & Y & Keterangan \\
\hline 1 & Fi & 225 & 85 & Tinggi \\
\hline 2 & SM & 180 & 85 & Tinggi \\
\hline 3 & AS & 220 & 83 & Tinggi \\
\hline 4 & AZ & 220 & 82 & Tinggi \\
\hline 5 & TH & 220 & 82 & Tinggi \\
\hline 6 & AHi & 220 & 82 & Tinggi \\
\hline 7 & DCP & 220 & 80 & Tinggi \\
\hline 8 & LSY & 220 & 80 & Tinggi \\
\hline 9 & RN & 220 & 80 & Tinggi \\
\hline 10 & SE & 220 & 80 & Tinggi \\
\hline 11 & MF & 220 & 80 & Tinggi \\
\hline 12 & DNA & 220 & 80 & Tinggi \\
\hline 13 & F & 220 & 80 & Tinggi \\
\hline 14 & MR & 220 & 80 & Tinggi \\
\hline 15 & NI & 184 & 80 & Tinggi \\
\hline 16 & MI & 182 & 80 & Tinggi \\
\hline 17 & NP & 181 & 80 & Tinggi \\
\hline 18 & AH & & & Tinggi \\
\hline
\end{tabular}

Dari tabel diatas, diketahui bahwa peserta didik yang memiliki konsep diri yang baik dan prestasi belajar yang baik pula. Hal ini membuktikan bahwa konsep diri memiliki keterkaitan erat dengan prestasi belajar yang diperoleh peserta didik-peserta didik di sekolah. Baiknya prestasi belajar yang di capai oleh peserta didik tersebut di atas di karenakan kemampuannya secara fisik, psikis, motivasi diri, kepandaian, dan mampu menerima kegagalan serta memahami kelemahan dalam diri dijadikan sebagai pelajaran masa akan datang.

Tabel 4.3. Kontribusi konsep diri terhadap prestasi belajar peserta didik kelas XI pada SMAN I WOHA Kabupaten Bima Kategori sedang

\begin{tabular}{|c|l|c|c|c|}
\hline No & \multicolumn{1}{|c|}{ Responden } & X & Y & Keterangan \\
\hline 1 & ALD & 181 & 78 & Sedang \\
\hline 2 & IQ & 178 & 78 & Sedang \\
\hline 3 & AS & 182 & 76 & Sedang \\
\hline 4 & NI & 188 & 75 & Sedang \\
\hline 5 & AR & 187 & 75 & Sedang \\
\hline 6 & EM & 186 & 75 & Sedang \\
\hline 7 & LI & 178 & 75 & Sedang \\
\hline 8 & SA & 189 & 75 & Sedang \\
\hline 9 & AA & 173 & 75 & Sedang \\
\hline
\end{tabular}


Volume 2 Nomor 2

November 2019

DOI: 1033627

E-ISSN : 2614-3585

\begin{tabular}{|l|l|l|l|l|}
\hline 10 & AH & 170 & 74 & Sedang \\
\hline 11 & Abd. H & 183 & 73 & Sedang \\
\hline 12 & AM & 172 & 73 & Sedang \\
\hline 13 & YA & 164 & 73 & Sedang \\
\hline
\end{tabular}

Dari tabel di atas, di ketahui bahwa konsep diri peserta didik yang labil berindikasi pada prestasi belajarnya yang berada pada kategori cukup atau sedang peserta didik-peserta didik tersebut di atas kurang mampu mengendalikan berbagai aspek mengenai diri atau kepribadian sehingga dalam pencapaian prestasi belajar hasil yang di capai cukup memuaskan. Keadaan diri yang labil membuat peserta didik tersebut di atas menjalani kegiatan belajar hanya mengandalkan dan mengutamakan kemampuan intelektual sehingga pencapaian hasil belajar kurang memuaskan di karenakan dominasi factor intelektual saja.

Tabel 4.4. Kontribusi Konsep Diri Terhadap Prestasi Belajar Peserta didik kelas XI Pada SMAN I Woha Kabupaten Bima kategori rendah

\begin{tabular}{|c|l|c|c|c|}
\hline No & \multicolumn{1}{|c|}{ Responden } & X & Y & Keterangan \\
\hline 1 & IA & 178 & 72 & Rendah \\
\hline 2 & AS & 176 & 72 & Rendah \\
\hline 3 & I Ah & 174 & 72 & Rendah \\
\hline 4 & SW & 171 & 72 & Rendah \\
\hline 5 & RA & 171 & 72 & Rendah \\
\hline 6 & AS & 171 & 72 & Rendah \\
\hline 7 & IPD & 169 & 72 & Rendah \\
\hline 8 & MA & 155 & 72 & Rendah \\
\hline 9 & MF & & & Rendah \\
\hline
\end{tabular}

Berdasarkan hasil penelitian diatas menunjukan bahwa hubungan antara konsep diri memiliki hubungan yang kuat dengan prestasi belajar yang di peroleh peserta didik di sekolah. Hal tersebut berdasarkan hasil perhitungan di peroleh $r_{\text {hitung }}=0,772$, jika dibandingkan pada $r_{\text {tabel }}$ probalibilitas 0,05 atau $5 \%=0,312$ maka $r_{\text {hitung }}=0,772>r_{\text {tabel }}=0,312$. Ini menunjukkan bahwa koefisien korelasi tersebut signifikasi sehingga hipotesis alternative (Ha) yang berbunyi "ada korelasi antara konsep diri dengan prestasi belajar peserta didik kelas XI pada SMAN I WOHA Kabupaten Bima di terima.

\section{KESIMPULAN}

Berdasarkan hasil penelitian dapat disimpulkan beberapa hal yaitu Konsep diri yang di maksudkan dalam penelitian ini adalah cara memandang diri sendiri secara menyeluruh yang merujuk kepada kesadaran tentang dirinya sendiri, kesadaran tentang fungsi keberadaannya, tidak hanya menyangkut persepsi tentang apa yang di pikirkan dan bagaimana pandangan individu akan dimensi fisiknya, psikis, motivasi, kepandaian, kegagalan atau kelemahannya di yang disebabkan oleh peristiwa konkrit yang dapat menimbulkan tingkah laku yang mempengaruhi antara lain meliputi bakat, minat, hasil belajar dan cita-cita. 

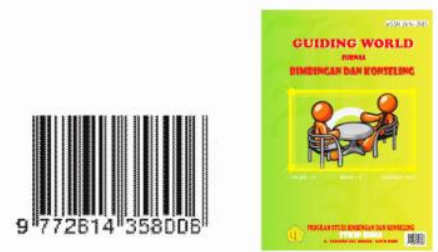

GUIDING WORLD JURNAL BIMBINGAN

DAN KONSELING

Volume 2 Nomor 2

November 2019

E-ISSN : 2614-3585

DOI: 1033627

Prestasi belajar peserta didik adalah hasil belajar dari suatu aktivitas belajar yang di lakukan berdasarkan pengukuran dan penilaian terhadap hasil kegiatan belajar dalam bidang akademik yang di wujudkan berupa angka-angka dalam raport pada peserta didik SMAN I Woha Kabupaten Bima.

Hasil penelitian diketahui bahwa konsep diri memiliki hubungan yang kuat dengan prestasi belajar. Hal ini di buktikan dengan hasil perhitungan dengan menggunakan product moment, dimana $r_{\text {hitung }}=0,772$, jika di hubungkan dengan $\mathrm{r}_{\text {tabel }}$ pada signifikan 5\% =0,312. Maka Hal ini menunjukkan bahwa koefisien korelasi tersebut signifikan sehingga hipotesis alternatif (Ha) yang berbunyi "ada korelasi antara konsep diri dengan prestasi belajar peserta didik kelas XI pada SMAN 1 WOHA Kabupaten Bima diterima.

Implikasi penelitian ini adalah Untuk mengembangkan dan mengoptimalkan konsep diri yang berperan dalam keberhasilan peserta didik baik di lingkungan sekolah maupun di lingkungan masyarakat, maka di sarankan kepada pi sekolah terutama guru Bimbingan dan Konseling, maupun guru-guru peng agar memberikan bimbingan khusus atau penyampaian materi konsep diri. Supaya peserta didik dapat memahami tentang diri yang sesungguhnya dengan proses secara sistimatis salah satunya dengan memberikan materi pengembangan diri.

\section{DAFTAR RUJUKAN}

Arikunto, S. 2002. Prosedur Penelitian Suatu Pendekatan Praktek. Rineka Cipta : Jakarta.

Arifin, Z. 1979. Bimbingan dan Dasar-dasar Pelaksanaan Teknik Bimbingan Praktis. Rajawali : Jakarta.

Depdikbud. 1990. Metodologi Penelitian. Modul Akta V : Jakarta

Djumhur, I. Surya, M. 1981. Bimbingan dan Konseling di Sekolah (Guide and Counseling). CV. Ilmu : Bandung

Hadi, S. 1977. Metodologi Rsearch Jilid 3. Andi Offset : Yogyakarta

Http : // www. KKM - KTSP. Com

Kartono, K. 1982. Teknik Bimbingan dan Penyuluhan. Bina Aksara : Jakarta

Loekmono. 1982. Psikologi Kepribadian. Bina Aksara : Jakarta

Natawidjaya, R. 1987. Peranan Guru Dalam Bimbingan di Sekolah. Abordion : Bandung

Nurkencana, Wayan. 1983. Evaluasi Pendidikan. Surabaya : Usaha Nasional

Pudjijogyanti, C. R. 1988. Konsep diri dalam proses belajar mengajar. Jakarta; pusat.

Riduwan 2009. Belajar Mudah Meneliti. Bandung: Alfabeta.

Siregar, S. 2012. Statistic Parametrik untuk Penelitian Kuantitatif. Jakarta: Bumi Aksara

Slameto. 2003. Belajar dan Faktor-faktor yang Mempengaruhinya. Jakarta : Rineka Cipta

Soemanto, Wasty. 1983. Psikologi Pendidikan. Jakarta : Rineka Cipta

Sudijono, Anas. 1998. Pengantar Evaluasi Pendidikan. Jakarta : PT RajaGrafindo Persada.

Sugiyono, 2009. Statistik Untuk Penelitian. Bandung. Alfabeta

Faijin, Nurhayati, Muhamadiah

Korelasi Antara Konsep Diri

Jurnal Guiding World

dengan Prestasi Belajar Peserta Didik

Vol. 2 No. 2 Nov. 2019 
Volume 2 Nomor 2

November 2019

E-ISSN : 2614-3585

Alfabeta

2008. Metode Penelitian Kuantitatif dan Kualitatif. Bandung.

Sukardi, Ketut Dewa. 1983. Bimbingan dan Penyuluhan Belajar di Sekolah. Usaha Nasional : Surabaya

Sunartana. 1976. Perkembangan Remaja. Tarsito : Bandung.

Sukmadinata, 2010. Metode Penelitian Pendidikan. Bandung. Rosda Karya

Usman, A, 2008. Mari Belajar Meneliti. Yogyakarta. Genta Press

Undang-undang RI No. 20 Tahun 2003 Tentang Sistem Pendidikan Nasional (SISDIKNAS). Citra Umbara : Bandung

Winkel, WS. 1984. Pengantar Ilmu Pendidikan. Surabaya : Usaha Nasional

Winarno. 1979. Teknik BP Individual. Jakarta

Witherington S.W. 1978. Psikologi Pengajaran. Gramedia : Jakarata 